DOI: 10.31393/reports-vnmedical-2021-25(3)-08

UDC: $572.087: 159.922$

\title{
EVALUATION OF THE LEADING TYPOLOGICAL CHARACTERISTICS OF TEMPERAMENT, SEVERITY AND FEATURES OF ACCENTUATED PERSONALITY TRAITS AND PSYCHODYNAMIC FEATURES OF PERSONALITY IN PRACTICALLY HEALTHY WOMEN WITHOUT AND TAKING INTO ACCOUNT THE SOMATOTYPE
} Andriievskyi I. I.

National Pirogov Memorial Medical University, Vinnytsya (Pyrogov street 56, Vinnytsya, Ukraine, 21018)

Responsible for correspondence. e-mail: nolenole4@gmail.com

Received: June, 03, 2021; Accepted: July, 28, 2021

\begin{abstract}
Annotation. Research on the relationship of the human body with its psychological characteristics and behavioral elements is currently of great value for integrative medicine, psychology and pedagogy. A deep understanding of this issue allows you to prevent and correct unwanted psychological manifestations in groups of people who have this predisposition, as well as help to find the right approach in educational and therapeutic work with such people. The purpose of the study is to evaluate the leading typological characteristics of temperament, severity and features of accentuated personality traits and psychodynamic personality traits of almost healthy women without and taking into account the somatotype. Primary anthropo-somatotypological and personality indicators of practically healthy Ukrainian women aged 21 to 35 years of different somatotypes were selected from the database of materials of the research center of National Pirogov Memorial Medical University, Vinnytsya. All women were evaluated by Eysenck leading typological characteristics of temperament with the help of personal questionnaires; psychodynamic features of Spielberger's personality in Khanin's modification; expressions and features of accentuated personality traits according to Shmishek. Statistical processing of the results was performed in the license package "Statistica 5.5" using non-parametric evaluation methods. It was found that almost healthy women without somatotype are characterized by extroversion (32.67\%) and ambiversion (29.70\%), average level of neuroticism (35.64 \%), insincerity (66.34\%), average level of anxiety (62.38\%), predominance of hyperthymic (33.66 \%), exalted (25.74 \%), cyclothymic (22.77\%) type of character accentuation. Women of mesomorphic somatotype are characterized by potential extroversion (33.33\%) and potential introversion (27.27\%), potentially high levels of neuroticism (39.39\%), insincerity (72.73\%), average level of anxiety (60.61\%), high level of personal1 anxiety (60.61\%), predominance of exalted (42.42\%), hyperthymic (30.30\%), cyclothymic (27.27\%) and emotional (24.24\%) types of character accentuation. Among women of ectomorphic somatotype, the most common are individuals with ambiversion (31.82\%) and potential extroversion (31.82\%), with a medium level of neuroticism (36.36 \%), insincerity (72.73 \%), high and medium levels of situational anxiety (50.00\% each), high personal anxiety (54.55\%), the predominance of hyperthymic (22.73\%), cyclothymic (18.18\%) and pedantic (18.18\%) types of character accentuation. Among women of endomesomorphic somatotype, the most common are those with potential introversion (31.82\%), ambiversion (36.36\%) and potential extroversion (27.27\%), with an average level of neuroticism (63.64\%), sincerity (50.00\%), an average level of situational ( $77.27 \%)$, the average level of personal anxiety (68.18\%), a significant predominance of the hyperthymic type of character accentuation (40.91\%). Among women with average intermediate somatotype, the most common are individuals with ambiversion (41.18\%) and potential extroversion (35.29\%), with medium and potentially high levels of neuroticism ( $29.41 \%$ in both cases), insincerity (76.47\%), average situational (58.82\%) and personal anxiety (70.59\%), the predominance of (significant) hyperthymic (52.94 \%) and cyclothymic (35.29\%) types of character accentuation. Thus, to study the psychological characteristics of people of different constitutional types, it is important to follow an interdisciplinary approach, in which the optimal use of traditional anthropometric techniques in combination with psychological tests.
\end{abstract}

Keywords: practically healthy women, somatotype, extroversion, neuroticism, anxiety, character accentuation.

\section{Introduction}

In many countries, young women are identified as a high-risk group because they are much more likely than men to suffer from various psychosomatic and neuropsychiatric disorders. However, psychological features taking into account somatotypes in this category of persons are insufficiently studied, which can complicate the prediction and prevention of possible diseases, the success of professional selection and growth, planning health measures, medical care $[6,10,17]$.

Research on the relationship of the human body with its psychological characteristics and behavioral elements is currently of great value for integrative medicine, psychology and pedagogy. Somatotyping is important for the diagnosis and prognosis of the psychological state of a healthy person. However, the problem of the relationship of different constitutions and mental characteristics is only part of a more general problem of correlations between the features of morpho-physiological organization and human behavior [2, 5, 15].

A deep understanding of this issue allows you to prevent and correct unwanted psychological manifestations in groups of people who have this predisposition, as well as help to find the right approach in educational and therapeutic work. It is important to emphasize the relevance of a 
comprehensive approach to the study of the characteristics and relationships of private - psychodynamic (type of temperament or personality) and neurodynamic (type of nervous system) constitutions.

The purpose of the study is to evaluate the leading typological characteristics of temperament, severity and features of accentuated personality traits and psychodynamic personality traits of practically healthy women without and taking into account the somatotype.

\section{Materials and methods}

Primary anthropo-somatotypological and personality indicators of practically healthy Ukrainian women aged 21 to 35 years of different somatotypes were selected from the database of materials of the research center of National Pirogov Memorial Medical University, Vinnytsya.

All women were assessed with the help of personal questionnaires by leading typological characteristics of temperament according to G. Eysenck; psychodynamic features of personality according to C. D. Spielberger in modification of $\mathrm{Yu}$. L. Khanin; severity and features of accentuated personality traits by $\mathrm{G}$. Shmishek [3, 19].

Statistical processing of the results was performed in the license package "Statistica 5.5" using non-parametric evaluation methods. The reliability of the difference between the values between the independent quantitative values was determined using the Mann-Whitney U-test.

\section{Results. Discussion}

Among the typologies of temperament, special attention is drawn to those in which the properties, understood as innate or hereditary, are directly related to individual differences in physique. It can be assumed that the physique should be associated only with relatively stable mental functions that do not change over weeks or even years. Therefore, first of all it is necessary to find mental signs that can be measured and have low intra-individual and high inter-individual variability $[1,13]$.

Kretschmer first identified two types of temperament cyclothymic and schizothymic, which more or less corresponded to the extrovert and introvert type of Jung. Kretschmer associated them with body types: cyclothymia with a picnic physique, schizothymia - with leptosomal. He later described the type of temperament characteristic of an athletic physique. Extroversion is a kind of characteristic of individual psychological differences of the individual, the extreme poles of which correspond to the orientation of the individual to the world of external objects (extraversion), or the phenomenon of his own subjective world (introversion) [7].

Psychological examination of women of the general group and different body types did not reveal significant differences and tendencies of differences on the scale of extraversion - introversion. A small number of subjects identified extreme variants of values on this scale, which did not dramatically affect the average values of the level of extroversion in the general group, in representatives of different somatotypes and were within ambiversion.

The percentage of women mesomorphs with introversion has a slight tendency to higher values $(p=0.096)$ compared to women endo-mesomorphic (12.12\% and 0 $\%$, respectively). The percentage of subjects with a mean intermediate somatotype with ambiversion has a slight tendency to higher values $(p=0.085)$ compared with mesomorphic women (41.18\% and $18.18 \%$, respectively).

The percentage distribution by level of extraversion, most characteristic of a certain group of subjects, is as follows: the general group is dominated by individuals with potential extroversion (32.67\%) and ambiversion (29.70\%); among mesomorphs - with potential extroversion (33.33\%) and potential introversion (27.27\%); among ectomorphs - with ambiversion (31.82 \%) and potential extroversion (31.82\%); among endo-mesomorphs - with potential introversion (31.82 \%), ambiversion (36.36 \%) and potential extroversion $(27.27 \%)$; among women with a middle intermediate somatotype - with ambiversion (41.18\%) and potential extroversion (35.29\%).

According to Eysenck, the degree of extraversion and introversion is associated with the level of activation of the reticular formation, and neuroticism - with the activity of the limbic system. Neuroticism (emotional instability) is associated with a tendency to evaluate perceived events and objects as more passive, disordered, weaker and negative. It is a continuum from normal affective stability to pronounced emotional lability. Thus, a score of $0-11$ points indicates emotional stability and corresponds to a low background of excitement produced by the limbic system. The average score on the scale of neuroticism is in the range of 12-13 points. An index of 14-24 points is an indicator of emotional instability [19].

It was found that the indicator on the scale of neuroticism is significantly $(p<0.05)$ higher in women mesomorphs $(12.91 \pm 5.05$ points) and has a slight tendency $(p=0.095)$ to higher values in the studied general group $(13.09 \pm 4.41$ points) compared to endo-mesomorphs $(11.73 \pm 3.07$ points).

The percentage of people with too low a level of neuroticism (superconcordants) has a slight tendency $(\mathrm{p}=0.083)$ to higher values in ectomorphs compared to mesomorphs $(9.09 \%$ and $0 \%$, respectively). The percentage of persons with an average level of neuroticism (normosthenics) was significantly $(p<0.05)$ lower in the general group of women compared with endo-mesomorphs (35.64 \% and $63.64 \%$, respectively). The percentage of people with an average level of neuroticism is significantly $(p<0.05-0.01)$ lower in women of mesomorphic and middle intermediate somatotype and tends $(p=0.078)$ to lower values in ectomorphs compared to endo-mesomorphs (respectively $24.24 \%, 29.41 \%, 36.36 \%$ and $63.64 \%$ ). The percentage of individuals with a potentially high level (potential discordant) of neuroticism is significantly $(p<0.05-0.01)$ higher in women of mesomorphic and middle intermediate somatotype and has a slight tendency $(p=0.086)$ to higher values in ectomorphs compared to endo-mesomorphic 
(respectively $39.39 \%, 29.41 \%, 22.73 \%$ and $4.55 \%$ ).

The percentage distribution by the level of neuroticism in the study groups is as follows: the general group is dominated by individuals with an average level of the indicator (35.64\%); among mesomorphs - with a potentially high level of the indicator (39.39\%); among ectomorphs with an average level of the indicator (36.36\%); among endomorphs - with an average level of the indicator (63.64 $\%)$; among women with an average intermediate somatotype - with an average and potentially high level of the indicator $(29.41 \%$ in both cases)

The average values according to the Eysenck insincerity scale in all subjects did not exceed 4 . The tendency to give questions to socially desirable answers was most often observed in representatives of the middle intermediate somatotype $(76.47 \%)$, ectomorphs $(72.73 \%)$ and mesomorphs (72.73\%).

Most often, anxiety is assessed in its relationship with self-esteem, motivation, components of personality. The relationship between anxiety and somatotype is analyzed by a number of authors, and data on this issue are presented in the scientific literature very contradictory and ambiguous $[9,16,18]$. Anxiety - one of the main components included in the structure of individual differences, is a subjective manifestation of impaired interaction of the individual with the environment. On the one hand, the optimal level of situational anxiety is an important, natural condition for personal activity and achieving the best results. Anxiety here acts as one of the conditions for predicting difficulties in performing a particular activity. On the other hand, high or too low levels of anxiety will interfere with the normal development of adaptation processes [4].

One of the main sources of personal anxiety is considered to be some innate properties of temperament, primarily emotional sensitivity, character accentuation and high neuroticism. Personal anxiety as an energetic aspect of the subject's activity is one of the manifestations of the most important feature of temperament - emotional instability. Anxiety also reflects the intensity of emotional and volitional processes [12]

The average value of the level of situational (reactive) anxiety according to Spielberger between the comparison groups has no significant differences and is within a moderate degree of the indicator.

The percentage of people with a moderate level of situational anxiety tends $(p=0.067)$ to lower values in subjects with ectomorphic somatotype compared with endomesomorphs $(50.00 \%$ and $77.27 \%$, respectively). The percentage of people with a high level of situational anxiety tends $(p=0.067)$ to higher values in ectomorphs compared to endo-mesomorphs (50.00\% and $22.73 \%$, respectively).

The Spielberger personal anxiety index was significantly $(p<0.01)$ lower in endo-mesomorphs $(40.32 \pm 7.89$ points $)$ compared with the general group of subjects $(44.46 \pm 8.93$ points). This indicator is significantly $(p<0.05)$ lower in endomesomorphs (40.32 \pm 7.89 points) and has a slight tendency $(p=0.081-0.088)$ to lower values in the representatives of the middle intermediate somatotype $(42.81 \pm 8.04$ points $)$ compared to mesomorphs $(46.09 \pm 8.24$ points) and ectomorphs (47.27 \pm 9.47 points).

The percentage of persons with an average level of personal anxiety was significantly $(p<0.05)$ lower in women of mesomorphs compared to representatives of endomesomorphic and middle intermediate somatotype (39.39 $\%, 68.18 \%$ and $70.59 \%$, respectively).

The percentage of people with a high level of personal anxiety has a slight tendency $(p=0.092)$ to lower values in women with a medium intermediate somatotype compared to the general group ( $23.53 \%$ and $45.54 \%$, respectively). This level of personal anxiety occurs significantly $(p<0.05)$ more often in mesomorphic women $(60.61 \%)$ and tends $(p=0.058-0.073)$ to higher values in ectomorphs $(54.55 \%)$ compared to endo-mesomorphic $(27.27 \%)$ and average intermediate $(23.53 \%)$ somatotypes.

It is known that personal anxiety is a constant category and is determined by the type of higher nervous activity, character, temperament, upbringing, acquired strategies to respond to external factors. Situational anxiety depends more on current problems and experiences. Usually, the indicators of situational and personal anxiety are interrelated: in people with high rates of personal anxiety, situational anxiety is manifested to a greater extent [8].

Among all groups of subjects, a high level of situational anxiety is most often observed in women ectomorphs $(50.00$ $\%)$ and less often in women of endomorphic (22.73\%), middle intermediate $(29.41 \%)$ and mesomorphic (39.39 $\%)$ somatotypes. The average level of situational anxiety is most often observed in women of endo-mesomorphic (77.27 $\%)$ and somewhat less often - in representatives of mesomorphic $(60.61 \%)$, intermediate $(58.82 \%)$ and ectomorphic $(50.00 \%)$ somatotypes.

High levels of personal anxiety are most often observed in women of mesomorphs (60.61\%), ectomorphs (54.55 $\%$ ) and less often in women of endomorphic (27.27\%) and middle intermediate $(23.53 \%)$ somatotypes. The average level of personal anxiety is most often observed in women of medium intermediate $(70.59 \%)$ and endo-mesomorphic $(68.18 \%)$ somatotypes and less often in women of ectomorphic (45.45\%) and mesomorphic (39.39\%) somatotypes.

Ernst Kretschmer (1930) classified the types of temperaments on the basis of body features. He believed that in completely healthy people you can find embryos for such a disease as schizophrenic or circular psychosis. Somatotype is a biological factor, and therefore character accentuation is also innate. Even in a healthy person, we can determine the predisposition to schizophrenic and circulatory syndrome. Such individuals are at risk of this pathology and under certain exogenous and endogenous factors, their condition can progress to the premorbid stage, and then to the disease [7]. If the transition from a state of health to certain disorders is determined in time, it is quite 
possible to prevent the occurrence of serious mental illnesses.

The rate of accentuation of the character of the hyperthymic type according to Shmishek tends ( $p=0.075$ 0.099 ) to higher values in the representatives of the middle intermediate somatotype ( $18.00 \pm 6.00$ points) compared with the general group $(15.18 \pm 6.35$ points) and mesomorphs (15.09 \pm 6.30 points).

The percentage of people with no accentuation of character by hyperthymic type is significantly $(p<0.05)$ lower in women with average intermediate somatotype (23.53\%) and tends $(p=0.076-0.081)$ to lower values in endomesomorphs (31.82\%) and in general groups of women (38.61\%) compared with ectomorphic somatotype (59.09 $\%)$. The percentage of persons with the presence of character accentuation by hyperthymic type tends $(p=0.059)$ to higher values in the representatives of the middle intermediate somatotype $(52.94 \%)$ compared with the representatives of the ectomorphic somatotype (22.73\%).

According to Shmishek, the character accentuation index of the emotional type tends $(p=0.069)$ to higher values in mesomorphs (16.55 \pm 4.81 points) compared to endomesomorphs (14.05 \pm 4.85 points).

The rate of accentuation of the character of the pedantic type according to Shmishek is significantly $(\mathrm{p}<0.05)$ higher in representatives of mesomorphic $(13.88 \pm 3.60$ points) and middle intermediate somatotypes ( $14.35 \pm 3.62$ points) and tends $(p=0.080)$ to higher values in the general group of women (13.21 \pm 4.69 points) compared with endomesomorphs ( $11.45 \pm 4.67$ points).

The percentage of people with no accentuation of character by the pedantic type is significantly $(\mathrm{p}<0.05)$ lower in women with average intermediate somatotype (23.53\%) and tends $(p=0.051-0.052)$ to lower values in the general group of women (40.59\%) and mesomorphs (36.36\%) compared with representatives of the endo-mesomorphic somatotype (63.64\%). The percentage of people with a tendency to develop accentuation by the pedantic type is significantly $(p<0.05-0.01)$ higher in the general group of women $(51.49 \%)$, in subjects with intermediate $(70.59 \%)$ and mesomorphic (60.61\%) somatotypes compared with endo-mesomorphic somatotype $(27.27 \%)$. The percentage of people with a tendency to develop accentuation by the pedantic type tends $(p=0.073)$ to lower values in subjects with a mean intermediate somatotype $(70.59 \%)$ compared with ectomorphs $(40.91 \%)$. The percentage of persons with the presence of character accentuation by the pedantic type tends $(p=0.061)$ to higher values in ectomorphs $(18.18 \%)$ compared to mesomorphs (3.03\%).

The rate of accentuation of the character of the exalted type according to Shmishek is significantly $(p<0.05)$ lower in ectomorphic somatotypes $(15.27 \pm 5.15$ points) and has a slight tendency $(p=0.095)$ to higher values in the general group of women $(16.93 \pm 5.12$ points) compared to mesomorphs (18.73 \pm 5.36 points).

The percentage of people with no accentuation of character by exalted type is significantly $(p<0.05)$ higher in women of ectomorphs (59.09\%) compared to mesomorphs $(27.27 \%)$. The percentage of persons with the presence of character accentuation by exalted type is significantly $(p<0.05)$ lower in women endo-mesomorphs $(13.64 \%)$ and tends $(p=0.071-0.76)$ to lower values in the general group of women $(25.74 \%)$ and ectomorphs $(18.18 \%)$ compared with mesomorphs (42.42\%).

According to the indicator of accentuation of the nature of the stuck, anxious, cyclothymic, demonstrative, excitable, dysthymic type, no significant differences and tendencies of differences have been established between different groups of the studied.

Accentuations of characters are based on the strength of the nervous system (strong - weak) and the speed of its excitability. Interestingly, character is an innate phenomenon, and appearance and physique reflect a person's character. According to the theory of character definition "7 radicals", any human character is a combination of 7 accentuations in different combinations [11, 14].

In the general group of subjects, the following percentage distribution of types of accentuation was revealed: hyperthymic - in $33.66 \%$; stuck - at $2.97 \%$; emotional - in $16.83 \%$; meticulous - in $7.92 \%$; alarming - in $9.90 \%$; cyclothymic - in $22.77 \%$; demonstrative - in $9.90 \%$; exciting - in $9.90 \%$; dysthymic - in $2.97 \%$; exalted type - in $25.74 \%$.

In mesomorphs: hyperthymic - in $30.30 \%$; stuck - in 3.03 $\%$; emotional - in $24.24 \%$; meticulous - in $3.03 \%$; alarming - in $15.15 \%$; cyclothymic - in $27.27 \%$; demonstrative - in $12.12 \%$; exciting - in $12.12 \%$; dysthymic - in $6.06 \%$; of the exalted type - at $42.42 \%$.

In ectomorphs: hyperthymic - in $22.73 \%$; stuck - in $0 \%$; emotional - in $13.64 \%$; pedantic - in $18.18 \%$; alarming - in $4.55 \%$; cyclothymic - in $18.18 \%$; demonstrative - in $13.64 \%$; exciting - in $4.55 \%$; dysthymic - in $4.55 \%$; exalted type - in $18.18 \%$.

In endo-mesomorphs: hyperthymic - in $40.91 \%$; stuck at $4.55 \%$; emotional - in $13.64 \%$; pedantic - in $9.09 \%$; alarming - in $4.55 \%$; cyclothymic - in $13.64 \%$; demonstrative - in $9.09 \%$; exciting - in $9.09 \%$; dysthymic - in $0 \%$; of the exalted type - at $13.64 \%$.

In representatives of the middle intermediate somatotype: hyperthymic - in $52.94 \%$; stuck - at $5.88 \%$; emotional - in $17.65 \%$; meticulous - in $5.88 \%$; alarming - in $11.76 \%$; cyclothymic - in $35.29 \%$; demonstrative - in $5.88 \%$; exciting - in $5.88 \%$; dysthymic - in $0 \%$; exalted type - in $23.53 \%$.

Thus, the predominance of accentuation of the character of the hyperthymic type among all studied comparison groups, a significant percentage of cyclothymic and exalted type in the general group and in representatives of the mesomorphic and middle intermediate somatotype; emotional - in mesomorphs.

As a result of the conducted researches the following psychological portraits at practically healthy women without consideration of a somatotype and at groups with various types of a physique are established: 
- women without somatotype are characterized by extroversion (32.67\%) and ambiversion (29.70\%), average level of neuroticism (35.64\%), insincerity (66.34\%), average level of anxiety (62.38\%); predominance of hyperthymic (33.66 \%), exalted $(25.74 \%)$, cyclothymic $(22.77 \%)$ types of character accentuation;

- among mesomorphs, the subjects with potential extroversion (33.33\%) and potential introversion (27.27\%), with a potentially high level of neuroticism (39.39\%), insincerity $(72.73 \%)$, an average level of anxiety (60.61\%), a high level of personal anxiety), the predominance of exalted (42.42\%), hyperthymic (30.30\%), cyclothymic (27.27\%) and emotional (24.24\%) types of character accentuation;

- among ectomorphs, the most common are individuals with ambiversion (31.82\%) and potential extroversion (31.82 $\%)$, with an average level of neuroticism (36.36\%), insincerity (72.73 \%), high and medium level of situational anxiety (50.00 $\%$ each), high level of personal anxiety. (54.55\%), the predominance of hyperthymic (22.73\%), cyclothymic (18.18 $\%)$ and pedantic (18.18\%) types of character accentuation;

- among endo-mesomorphs - with potential introversion (31.82 \%), ambiversion (36.36\%) and potential extroversion $(27.27 \%)$, with an average level of neuroticism (63.64\%), sincerity $(50.00 \%)$, an average level of situational $(77.27 \%)$ and personal anxiety (68.18\%), a significant predominance of the hyperthymic type of character accentuation (40.91\%);

- among women with average intermediate somatotype - with ambiversion (41.18\%) and potential extroversion (35.29\%), with medium and potentially high levels of neuroticism (29.41\% in both cases), insincerity $(76.47 \%)$, average situational (58.82 \%) and personal anxiety $(70.59$ $\%)$, the predominance of (significant) hyperthymic (52.94\%) and cyclothymic (35.29\%) types of character accentuation.

Thus, the study allowed to characterize and compile "psychological portraits" of practically healthy young women of four somatotypes. The above results of the study prove that there is a relationship between the human constitution and its psychological characteristics. This fact must be taken into account in both medical and educational institutions, where it is necessary to assess the mental state of a person depending on his constitutionally determined tendencies.

\section{References}

[1] Allemand, M., Steiger, A. E., \& Hill, P. L. (2013). Stability of personality traits in adulthood: Mechanisms and implications. Journal of Gerontopsychology and Geriatric Psychiatry, 26, 5-13. doi: 10.1024/1662-9647/a000080

[2] Dzhamalova, B. B., Magomedov, G. B., Amirkhanov, A. A., Ramazanova, P. K., \& Suleymanov, B. B. (2016). Anthropological mechanisms of self-management of personality behavior. International Review of Management and Marketing, 6(2), 383389. ISBN 2146-4405

[3] Eliseev, О. Р. (2017). Практикум по психологии личности : учеб. пособие для бакалавриата и магистратуры (4-е изд., перераб. и доп.) [Practicum on Personality Psychology: Study Guide for Bachelor's and Master's Degrees (4th edition, revised and enlarged)]. М.: Издательство Юрайт - М.: Publishing house Yurayt. ISBN 978-5-534-04901-5

[4] Goryachev, V. V. (2013). Проблема конституции и конститу-

\section{Conclusions and prospects for further development}

1. The study compiled "portraits" of mesomorphic, ectomorphic, endo-mesomorphic and middle intermediate somatotypes of practically healthy young women in terms of extraversion, insincerity, level of situational and personal anxiety, types of character accentuation that can be used in hygienic assessment and state of mental health of different body composition of the contingent during preventive examinations.

2. Among the studied women without taking into account the somatotype, ectomorphs, women with a middle intermediate somatotype, persons with potential extroversion and ambiversion predominated; among mesomorphs - with potential extroversion and introversion; among endomesomorphs - with ambiversion, potential introversion and extroversion.

3. Representatives of mesomorphic and middle intermediate somatotypes have a potentially high level, and the general group of women, ectomorphs and endomesomorphs - an average level of neuroticism. The sincerest in their answers are the subjects with endomesomorphic somatotype.

4. High levels of situational anxiety are most often observed in ectomorphs, and personal anxiety - in mesomorphs and ectomorphs; the average level of situational and personal anxiety - in the studied other comparison groups.

5. The predominance of accentuation of the character of hyperthymic type among all studied comparison groups, a significant percentage of cyclothymic and exalted type in the general group and in representatives of mesomorphic and middle intermediate somatotype; emotional - in mesomorphs.

In further research it is planned to evaluate the features of typological delineation of emotional-dynamic pattern in practically healthy Ukrainian women without and taking into account somatotype, which will substantiate the psychohygienic significance of somatotype as an endogenous risk factor affecting the mental health status and psychological characteristics of people with different physique.

циональных различий в психологии и педагогике [The problem of constitution and constitutional differences in psychology and pedagogy]. Вестник Томского государственного педагогического университета - Bulletin of Tomsk State Pedagogical University, 6(134), 23-26.

[5] Kenneth, I. O., \& Matthew, B. M. (2013). Investigation of William H. Sheldon's Constitutional Theory of Personality: A Case Study of the University of the Gambia. Mediterranean Journal of Social Sciences, 4(7), 85. doi: 10.5901/mjss.2013.v4n7p85

[6] Kohlmann, S., Löwe, B., \& Shedden-Mora, M. C. (2018). Health care for persistent somatic symptoms across Europe: a qualitative evaluation of the EURONET-SOMA expert discussion. Frontiers in psychiatry, 9, 659-646. doi: 10.3389/ fpsyt.2018.00646

[7] Krechmer, E. (1999). Гениальные люди [Genius people]. Издво: Гуманитарное Агентство "Академический Проект" - 
Publishing house: Humanitarian Agency "Academic Project".

[8] Leal, P. C., Goes, T. C., da Silva, L. C. F., \& Teixeira-Silva, F. (2017). Trait vs. state anxiety in different threatening situations. Trends in psychiatry and psychotherapy, 39, 147-157. doi: 10.1590/2237-6089-2016-0044

[9] Ning, H. K., \& Downing, K. (2010). The reciprocal relationship between motivation and self-regulation: A longitudinal study on academic performance. Learning and Individual Differences, 20(6), 682-686. doi: 10.1016/j.lindif.2010.09.010

[10] Patton, G. C., Coffey, C., Romaniuk, H., Mackinnon, A., Carlin, J. B., Degenhardt, L., ... \& Moran, P. (2014). The prognosis of common mental disorders in adolescents: a 14-year prospective cohort study. The Lancet, 383(9926), 1404-1411. doi: 10.1016/ S0140-6736(13)62116-9

[11] Raigorodskii, D. la. (2004). Практическая психодиагностика. Методики и тесты [Practical psychodiagnostics. Methods and tests]. Самара: Издательский дом "Бахрах-М" - Samara: Publishing House "Bahrah-M".

[12] Raymond, J. G., Steele, J. D., \& Series, P. (2017). Modeling trait anxiety: From computational processes to personality. Frontiers in psychiatry, 8, 1. doi: 10.3389/fpsyt.2017.00001

[13] Ryckman, R. M. (2007). Theories of Personality (9th ed.). Cengage Learning. ISBN 9780495099086

[14] Shogren, K. A., Singh, N., Niemiec, R., \& Wehmeyer, M. L. (2017). Character strengths and mindfulness. Psychology, Social Psychology,
Clinical Psychology. https://www.oxfordhandbooks.com/ doi: 10.1093/oxfordhb/9780199935291.013.77

[15] Stewart, A., Crockett, P., Nevill, A., \& Benson, P. (2014). Somatotype: a more sophisticated approach to body image work with eating disorder sufferers. Advances in Eating Disorders: Theory, Research and Practice, 2(2), 125-135. doi: 10.1080/21662630.2013.874665

[16] Taras, M. (2010). Assessment for learning: assessing the theory and evidence. Procedia-Social and Behavioral Sciences, 2(2), 3015-3022. doi: 10.1016/j.sbspro.2010.03.457

[17] Waller, M., Lissner, L., Hange, D., Sundh, V., Blomstrand, A., \& Bj?rkelund, C. (2021). Well-being and mental stress in the population study of women in Gothenburg, Sweden: cohort comparisons from 1980 to 2016 of 36-year trends and socioeconomic disparities in 38-and 50-year old women. BMC public health, 21(1), 1-8. doi: 10.1186/s12889-021-10937-z

[18] Zaichenko, А. А. (2010). Конституциональная психология [Constitutional psychology]. Известия Саратовского университета. Новая серия. Серия Философия. Психология. Педагогика - Bulletin of the Saratov University. New series. Philosophy Series. Psychology. Pedagogy, 10(2), 64-69.

[19] Zentner, M., \& Shiner, R. L. (2012). Fifty years of progress in temperament research: A synthesis of major themes, findings, and challenges and a look forward. The Guilford Press. ISBN 9781462506514

\section{ОЦІНКА ПРОВІДНИХ ТИПОЛОГІЧНИХ ХАРАКТЕРИСТИК ТЕМПЕРАМЕНТУ, ВИРАЖЕНОСТІ ТА ОСОБЛИВОСТЕЙ АКЦЕНТУЙОВАНИХ РИС ОСОБИСТОСТІ ТА ПСИХОДИНАМІЧНИХ ОСОБЛИВОСТЕЙ ОСОБИСТОСТІ У ПРАКТИЧНО ЗДОРОВИХ ЖІНОК БЕЗ І 3 УРАХУВАННЯМ СОМАТОТИПУ}

\section{Андрієвський I. I.}

Анотація. Дослідження, присвячені взаємозв'язку тіла людини з ї психологічними особливостями та елементами поведінки на даний час становлять велику цінність для інтегративної медицини, психології та педагогіки. Глибоке розуміння даного питання дозволяє запобігти та скоригувати небажані психологічні прояви у груп осіб, які мають таку схильність, а також допоможе знайти правильний підхід в освітній та лікувальній роботі з такими людьми. Мета дослідження - оцінити провідні типологічні характеристики темпераменту, вираженість та особливості акцентуйованих рис особистості та психодинамічні особливості особистості практично здорових жінок без і з урахуванням соматотипу. Первинні антропо-соматотипологічні та показники особливостей особистості практично здорових українських жінок віком від 21 до 35 років різних соматотипів відібрані з банку даних матеріалів науково-дослідного центру Вінницького національного медичного університету ім. М. І. Пирогова. Усім жінкам за допомогою особистісних опитувальників проведено оцінку провідних типологічних характеристик темпераменту за Айзенком; психодинамічних особливостей особистості за Спілбергером в модифікації Ханіна; вираженості та особливості акцентуйованих рис особистості за Шмішеком. Статистичну обробку результатів проведено в ліцензійному пакеті "Statistica 5.5" із використанням непараметричних методів оцінки. Встановлено, що практично здоровим жінкам без урахування соматотипу притаманна екстравертованість (32,67 \%) і амбіверсія (29,70 \%), середній рівень нейротизму (35,64 \%), нещирість (66,34 \%), середній рівень тривожності (62,38 \%), переважання гіпертимного (33,66 \%), екзальтованого (25,74\%), циклотимного (22,77 \%) типу акцентуації характеру. Жінкам мезоморфного соматотипу притаманна потенційна екстравертованість (33,33 \%) і потенційна інтровертованість (27,27 \%), потенційно високий рівень нейротизму (39,39\%), нещирість (72,73\%), середній рівень тривожності (60,61\%), високий рівень особистісної тривожності (60,61%), переважання екзальтованого (42,42 \%), гіпертимного (30,30 \%), циклотимного (27,27 \%) і емотивного $(24,24 \%)$ типів акцентуації характеру. Серед жінок ектоморфного соматотипу найбільше зустрічаються особи з амбіверсією (31,82 \%) і потенційною екстравертованістю (31,82 \%), з середнім рівнем нейротизму (36,36 \%), нещирістю (72,73 \%), високим і середнім рівнем ситуативної тривожності (по 50,00 \%), високим рівнем особистісної тривожності (54,55 \%), переважанням гіпертимного (22,73 \%), циклотимного (18,18 \%) і педантичного (18,18 \%) типів акцентуації характеру. Серед жінок ендо-мезоморфного соматотипу найбільше зустрічаються особи з потенційною інтровертованістю (31,82 \%), амбіверсією (36,36 \%) і потенційною екстравертованістю (27,27 \%), з середнім рівнем нейротизму (63,64 \%), щирістю (50,00 \%), середнім рівнем ситуативної тривожності (77,27 \%), середнім рівнем особистісної тривожності (68,18 \%), значним переважання гіпертимного типу акцентуації характеру (40,91\%). Серед жінок з середнім проміжним соматотипом найбільще зустрічаються особи з амбіверсією (41,18 \%) і потенційною екстравертованістю (35,29 \%), з середнім і потенційно високим рівнем нейротизму (29,41 \% в обох випадках), нещирістю (76,47 \%), середнім рівнем ситуативної (58,82 \%) і особистісної тривожності (70,59 \%), переважанням (значним) гіпертимного (52,94\%) і циклотимного (35,29 \%) типів акцентуації характеру. Таким чином, для вивчення психологічних особливостей осіб різних конституціональних типів важливо дотримуватися міждисциплінарного підходу, при якому оптимальним є застосування традиційних антропометричних методик у поєднанні з психологічними тестами.

Ключові слова: практично здорові жінки, соматотип, нейротизм, екстравертованість, тривожність, акцентуація характеру. 